\title{
The Insular Landscape of the Old English Poem The Phoenix
}

\author{
Helen Appleton ${ }^{1}$ (D)
}

Published online: 7 August 2017

(C) The Author(s) 2017. This article is an open access publication

\begin{abstract}
The opening section of the Old English poem The Phoenix derives from a fourth-century Latin poem, Carmen de ave phoenice, which is usually attributed to Lactantius. It is well known that The Phoenix Christianises and substantially enlarges upon descriptive details derived from its Latin source, but little detailed work has been done on how this actually takes place. The poet of The Phoenix's expansions have been dismissed as prolix, yet when examined in light of similar passages elsewhere in the corpus of Old English literature, these additions can be seen to introduce images of particular resonance. This essay will focus on the landscape of the poem's opening to argue for the Anglo-Saxon poet's introduction of a distinctively insular spatial imaginaire to the setting inherited from the Latin source material. This insular imaginaire is in keeping with general trends in AngloSaxon literary culture, and ensures the resonance of The Phoenix's resurrection allegory with its Anglo-Saxon audience.
\end{abstract}

Keywords Old English · Anglo-Saxon · Islands · The Phoenix · Poetry · Exeter Book $\cdot$ Landscape $\cdot$ Translation

The Old English poem The Phoenix, found in the Exeter Book (fols. 55b-65b), describes the mythical bird, the Edenic landscape it inhabits and the cycle of death and rebirth that it enacts in an extended Christian allegory. John Josias Conybeare identified the opening 380 lines of The Phoenix as being an expanded translation of Carmen de ave phoenice, a fourth-century Latin poem usually attributed to Lactantius (Conybeare 1826, 224). This section of the Old English poem describes

Helen Appleton

helen.appleton@ell.ox.ac.uk

1 Balliol College, Broad Street, OX1 3BJ Oxford, UK 
the idyllic landscape inhabited by the phoenix - a delightful space that appears in contrast to the harsher landscapes that typify the natural world in Old English texts (Neville 1999). The Phoenix poet then transforms the phoenix into an explicit allegory of the resurrection in the concluding section of the poem. In the opening part of The Phoenix the Anglo-Saxon poet makes inventive use of Carmen de ave phoenice, Christianizing and substantially reconfiguring his material, especially the descriptive details associated with the phoenix itself, and with its idealized homeland. One such innovation is the depiction of the phoenix's home as an iglond and an ealond, words usually translated as 'island'. This article argues that the land inhabited by the phoenix is reimagined as an insular space as part of a comprehensively Christianizing and anglicizing descriptive strategy employed by the poet. The landscape inherited from the poem's source is reshaped in the opening of The Phoenix into an explicitly Christian allegory resonant for an Anglo-Saxon audience. This refashioning facilitates contemplation of the transitory nature of earthly things, the glory of Christ and his ultimate home in heaven, skilfully priming the audience for the eschatological material in the latter section of the poem.

Hilary Fox's work has shown how the poet of The Phoenix adapts his source's description of the bird in light of the importance of gold and craftsmanship in AngloSaxon culture, and the Christian tradition of God as crafter of the world (Fox 2012). Fox's analysis reveals that the visual world of the poem has been reshaped by the AngloSaxons' imaginaire. Fabienne Michelet defines the imaginaire as a set of images, shaped by shared experience, which underpins aspects of a culture (Michelet 2006, 5). A Christian worldview is a principal component of the Anglo-Saxon imaginaire, as is the experienced world of Anglo-Saxon England. The same pattern of embellishment driven by the Anglo-Saxon imaginaire that Fox identifies in the metalwork imagery of The Phoenix can be found in the landscapes of the poem, especially in the highly ornate description of the phoenix's home, with which the poem opens.

The opening 84-line section of The Phoenix, on which this article focuses, was aptly described by Henry Sweet in his Old English Reader as 'The Happy Land' (Sweet 1881, 163). It reveals both the poet's debt to his Latin source and the way in which the landscape of the poem has been reshaped for an Anglo-Saxon audience through their imaginaire. The phoenix dwells in a beautiful, fruitful land, without hostile features and sinful men. Comparison with the Latin text reveals that features derived from Carmen de ave phoenice are comprehensively reimagined and enlarged in the Old English poem. Conybeare noted the scale of the Anglo-Saxon poet's expansion of the source material, terming it a prolixity 'perhaps almost inseparable from the poetical system adopted by our ancestors' (Conybeare 1826, 224). But it is not simply the conventions of Old English verse, such as variation, that can account for the scale of the additions, nor are they prolix. As Brian Shaw notes, the alterations made by the poet of The Phoenix prepare for the Christian allegory that follows (Shaw 1989, 180). ${ }^{1}$ The Old English poem presents the phoenix in a Christian context that is absent from Carmen de ave phoenice. Classical mythology is replaced by Christian imagery and the entire landscape in

\footnotetext{
${ }^{1}$ Critics have seen the opening as connected to the resurrection allegory in various ways: as fluid (Kantrowitz 1964); as concerned with virginity (Bugge 1976); as related to purgatory (Muir 2000, 468).
} 
recast in Christian Anglo-Saxon imaginative terms, including the introduction of insular space. ${ }^{2}$ The poet imports imagery of a kind paralleled elsewhere in the Old English corpus and employs it to convert his source material into a Christian allegory of the resurrection, meaningful and intelligible to an Anglo-Saxon audience.

Although the beautiful landscape of 'The Happy Land' may appear atypical in Old English verse, particularly when placed next to the hostile, gloomy landscapes of poems such as The Wanderer and Wulf and Eadwacer, also found in the Exeter Book, the description is grounded in the same conventions. There is a remarkable consistency in the use to which particular landscape features are put in the corpus, such as winter weather as an image of the hostile waste. These associations are illustrated by the Anglo-Saxon gnomic wisdom tradition, exemplified by poems such as Maxims I and Maxims II. As Barbara Raw observes: 'the predictive statements of the gnomic poetry suggest that there was an agreed view of nature and of landscape' (Raw 1978, 48). This agreed view is evident in The Phoenix, which defines the land inhabited by the phoenix as idyllic partly by the absence of features associated with the harsh, waste-like landscapes. The Phoenix is also typical of the landscapes of Old English verse in the way in which it depicts a Christian perspective on the world. The role of God in controlling the landscape is explained, linking the land's perfection to its spiritual state.

The Phoenix begins by describing the eastern location of the bird's home, as does Carmen de ave phoenice, but introduces two new, key, interrelated ideas: that the land is separated from sin by God's power, and that it is insular: ${ }^{3}$

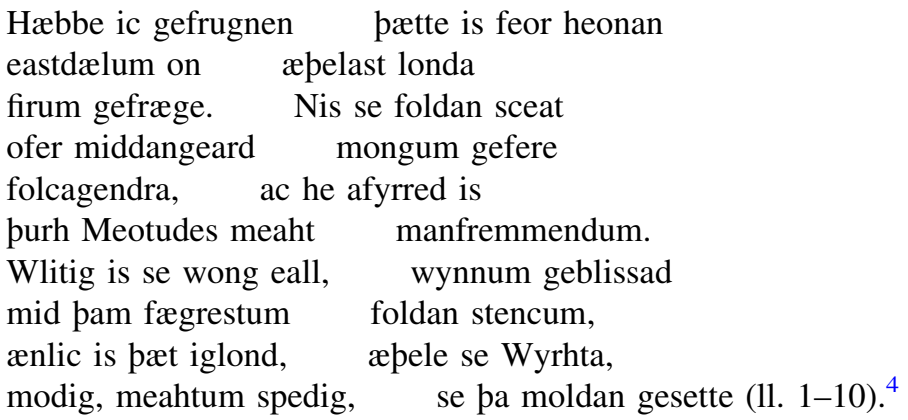

\footnotetext{
${ }^{2}$ For further discussion of the Christianization of the source material, how many lines of Phoenix are independent of Carmen de ave phoenice and which parts of the Latin poem are rejected by the AngloSaxon poet see Emerson (1926). Norman Blake (1961) has argued that the Phoenix poet was not the first to Christianize the imagery of Carmen de ave phoenice. Nevertheless, the manner in which the poem is Christianized is distinctly Anglo-Saxon..

${ }^{3}$ All Phoenix quotations taken from Blake (1990).

4 'I have heard that far from here there is, in eastern parts, the noblest of lands, renowned among men. That region of land is inaccessible to many rulers of people across the earth, but it is separated through God's might from sinful men. All that plain is beautiful, blessed in joy with the fairest of the earth's perfumes, singular is that island, noble the Creator who, spirited, abounding in might, established that earth.' In translating 1. 4b in this way I follow Blake and Emma Gorst, rather than Alfred Bammesberger, because, like Gorst, I feel that the depiction of the phoenix's land as Edenic supports the contention that all of sinful mankind are separated from it (Blake 1990, 68; Gorst 2006, 140; Bammesberger 2004). Translations are my own unless otherwise indicated.
} 
The insularity of the phoenix's home is an idea unique to the Old English text. In Carmen de ave phoenice it is simply described as a place in the East, but the AngloSaxon poet redefines and remaps the space. The poet returns to the image of the phoenix's insular home later in the poem (11. 285b-7a) when he describes the aftermath of the phoenix's self-immolation and rebirth: 'Ponne eal geadorl bebyrged beaducræftig ban ond yslanl on pam ealonde' ('Then the battle-crafty one buries the bone and cinders all together in that island'). Whether the landscape envisioned by the poet of The Phoenix was actually an island is a matter of considerable critical debate, but an examination of the alterations to the source material, and an analysis of similar unexpected islands in Old English verse, reveals that the 'aenlic iglond' forms a key part of the poet's anglicizing descriptive strategy, ensuring the resonance of the text with its Anglo-Saxon audience.

The image of 'The Happy Land', separated from sin, is not found in the Latin text, which simply reads 'est locus in primo felix oriente remotus' ('there is a remote, happy place in the distant east', 1. 1); this distancing is an important addition accounting for the Edenic state of the space. ${ }^{5}$ In the Christian understanding of the world integrated by the Anglo-Saxons, a landscape as perfect as that of The Phoenix cannot exist in the fallen world, where Adam's curse operates (Gen. 3.17): 'maledicta terra in opere tuo' ('cursed is the earth in thy work'). ${ }^{6}$ The depiction of the phoenix's home as insular (discussed in greater detail below) emphasizes its separation from the fallen creation occupied by man; the isolated, idealized landscape is integral to the poem's success as an allegory. As the poet later explains, the idyllic nature of the space reveals what has been lost in the Fall (11. 424-27), but Paradise can be regained by the righteous through resurrection. ${ }^{7}$

The shaping of The Phoenix's geography through an Anglo-Saxon perspective is exemplified by the poet's treatment of 11. 3-4 of Carmen de ave phoenice: 'nec tamen aestivos hiemisve propinquus ad ortus, I sed qua sol verno fundit ab axe diem' ('however, neither the summer nor winter sunrises are close, but the sun pours forth from the spring heavens'). The Latin is at pains to stress that although the phoenix's land is in the distant east, it is not to be thought of as a peripheral space as the sun comes from the centre, rather than an extreme; this approach reflects some of the concern with centrality and marginality that defines Classical and Late Antique geography (Michelet 2006, 6, 10). This dichotomy is not as fundamental to the Anglo-Saxon spatial imaginaire, which sees a space's marginality as determined by its nature. Therefore, the poet of The Phoenix demonstrates the centrality of the phoenix's blessed island not through geographic measures, but via its productive and temperate landscape, which lacks the unpleasant weather associated with marginal waste spaces in Old English verse. The section of The Phoenix corresponding to Carmen de ave phoenice 11. 3-4 is 11. 13-21a:

Pæt is wynsum wong, wealdas grene

rume under roderum. $\quad$ Ne mæg pær ren ne snaw

\footnotetext{
5 All quotations from Carmen de ave phoenice taken from Appendix I to Blake (1990).

6 All biblical quotations are taken from the Vulgate. Translations are from the Douay-Rheims.

7 For a detailed study of this theme see Brooks (2015).
} 


$\begin{array}{ll}\text { ne forstes fnæst } & \text { ne fyres blæst } \\ \text { ne hægles } h \text { ryre } & \text { ne } h \text { rimes dryre } \\ \text { ne sunnan hætu } & \text { ne sincaldu } \\ \text { ne wearm weder } & \text { ne winterscur } \\ \text { wihte gewyrdan, } & \text { ac se wong seomað } \\ e \text { adig ond } \text { onsund. } & \text { Is pæt } a \text { pele lond } \\ b \text { lostmum ge } b \text { lowen. } & \end{array}$

Enumeratio and anaphora (11. 14b-18b) combine with the intensely alliterative structure of these lines (all except 1. 17 feature double alliteration, italicized) to highlight the perfection of the space, protected from destruction and waste. ${ }^{9}$ In a series of images unparalleled in the Latin text the Old English poet defines the 'wynsum wong' by the absence of an extensive array of unpleasant weather phenomena associated with fallen and wasted lands in Old English verse, as in The Wanderer 1. 48 where 'hreosan hrim ond snaw, hagle gemenged' ('rime and snow fall, mingled with hail') (Muir 2000, 219). Using apophasis, the ideal space has been defined in terms intelligible to an Anglo-Saxon audience.

The Phoenix poet integrates imagery conventionally associated with Eden in the Christian poetic tradition into the landscape inherited from the Carmen de ave phoenice, and reshapes it in Anglo-Saxon imaginative terms. Emma Gorst and Janie Steen have separately argued that in 1l. 14-19 the poet of The Phoenix is drawing on Blossius Aemilus Dracontius's De laudibus dei I.180-193 (Gorst 2006, 136-37; Steen 2008, 48-49). The passage from Dracontius that Gorst and Steen identify as the source shares descriptive commonalities with The Phoenix, but they are not exact parallels, suggesting that stock Edenic imagery has been crafted by the poet to suit his particular aims. Dracontius comments on the absence of heat and cold from Eden, but does not construct the inclement weather in the contrasting hot/cold pairings employed by the poet of The Phoenix, nor does he place the cold weather first (Vollmer 1905, 32):

$$
\text { ... non solis anheli }
$$

flammatur radiis, quatitur nec flatibus ullis

nec coniuratis furit illic turbo procellis;

non glacies destricta domat, non grandinis ictus

verberat aut gelidis canescunt prata pruinis (I., 11. 189-193). ${ }^{10}$

In contrast the poet of The Phoenix begins his catalogue with 'ren ne snaw', emphasizing the cold, wet weather so often depicted as harmful in Anglo-Saxon

\footnotetext{
8 'That is a delightful plain, green woods spacious under the heavens. Neither rain nor snow, nor frost's breath, nor fire's blast, nor hail's destruction, nor rime's fall, nor the sun's heat, nor perpetual cold, nor hot weather, nor winter shower, may harm anything, but the plain abides, blessed and sound. That noble land is blooming with blossoms.'

9 A number of homilies, such as Vercelli X (Scragg 1992, 191-218), employ enumeratio and anaphora of this kind as part of a similarly apophatic approach. On apophasis in Anglo-Saxon literature, see Flight (2016).

10 '... it is not inflamed with the rays of the blowing sun, nor does it shake with any blasts, nor does a whirlwind rage in that place with conspiring storms; rigid ice does not subdue it, the blows of a hailstorm do not beat there, nor does icy-cold hoarfrost whiten the meadows.'
} 
texts, reflecting the English climate. Similar imagery to that of The Phoenix is found in other Anglo-Saxon texts that contrast Paradise with the fallen world, such as Adam's lament about the weather outside Eden in Genesis B 11. 805-12a (Doane 1991, 229), where, following the Old Saxon source (Doane 1991, 234), the hail and frost again precede heat. A similar connection between inclement weather and sin is found in Vercelli Homily X (Scragg 1992, 191-218), a penitential piece preserved in a large number of manuscripts (Szarmach 1981, 11; cf. Wilcox 1997). In these, and several other Anglo-Saxon texts, unpleasant weather is seen as a punishment for sin, but because 'The Happy Land' is separated from sinful men God's blessing remains, manifested in the perpetually temperate climate.

The Phoenix returns to the weather of 'The Happy Land' in 11. 57-62a, following a similar section of Carmen de ave phoenice (11. 21-24). The Old English reads:

\begin{tabular}{|c|c|}
\hline $\begin{array}{l}\text { intergeweorp, } \\
\text { under heofonum, } \\
\text { m cylegicelum, } \\
\text { he hægl ne } h \text { rim } \\
\text { indig wolcen, }\end{array}$ & $\begin{array}{l}\text { ne wedra gebregd, } \\
\text { ne se hearda forst, } \\
\text { cnyseð ænigne. } \\
\text { hreosað to foldan, } \\
\text { ne pær wæter feallep, }\end{array}$ \\
\hline
\end{tabular}

Again double alliteration (italicized) in 11. 57-61 draws attention to the imagery of this section. Both The Phoenix and Carmen de ave phoenice place this account after a description of the absence of disease and vice, features that to a Christian Anglo-Saxon would be deeply interconnected. Rather than simply demonstrating the poet of The Phoenix's prolixity, the repetition of these weather images reinforces the idea that sin and its effects are absent from this space, and can be seen as an essential part of the Christianization and anglicization of The Phoenix's landscape.

The Anglo-Saxon poet also exemplifies the contrast between the land of the phoenix and the rest of the fallen world through topography. The poet describes uneven and disruptive landforms (conventionally associated with wastes in Old English verse) as absent from 'The Happy Land':

Beorgas pær ne muntas
steape ne stondað, ne stanclifu

heah hlifiað, swa her mid us,

ne dene ne dalu ne dunscrafu,

hlæwas ne hlincas, ne pær hleonað oo

unsmepes wiht, ac se æela feld

wridað under wolcnum, wynnum geblowen.

Is pæt torhte lond twelfum herra,

folde fæðmrimes, swa us gefreogum gleawe

witgan purh wisdom on gewritum cypað,

11 '... no winter storm, nor vicissitude of weather, rough under the heavens, nor does the hard frost afflict any with cold icicles. There neither hail nor rime falls to earth, nor wind-driven cloud, nor does water fall there, agitated by wind.' 
ponne ænig para beorga pe her beorhte mid us

hea hlifiað under heofontunglum. (1l. 21b-32) $)^{12}$

Both Carmen de ave phoenice (11. 5-8) and The Phoenix describe a flat land that towers above the rest of the earth, but only the Old English text contrasts the high wong ('plain') with the hostile features of upland regions, the dene, dalu and dunscrafu associated with wastes in the Old English literary corpus, no doubt because of the experienced landscape of England. ${ }^{13}$ In The Phoenix these features are rendered more threatening by the use of adjectives such as steap and heah, creating an impression of dark structures towering over mankind. In contrast, 'The Happy Land' is repeatedly described as a wong, as is Paradise in $11.418 \mathrm{~b}$ and $439 \mathrm{a}$, while the fallen world is 'pas deaðdene' ('this valley of death') in $1.416 \mathrm{a} .{ }^{14}$ The phoenix's home lacks hlowas ('burial mounds'), common features of borders and wastes, suggesting an Edenic absence of death from the land, anticipating its figuring as a type of Paradise. ${ }^{15}$

The Phoenix continues the contrast between 'The Happy Land' and the waste by focusing on the immutable nature of the island:

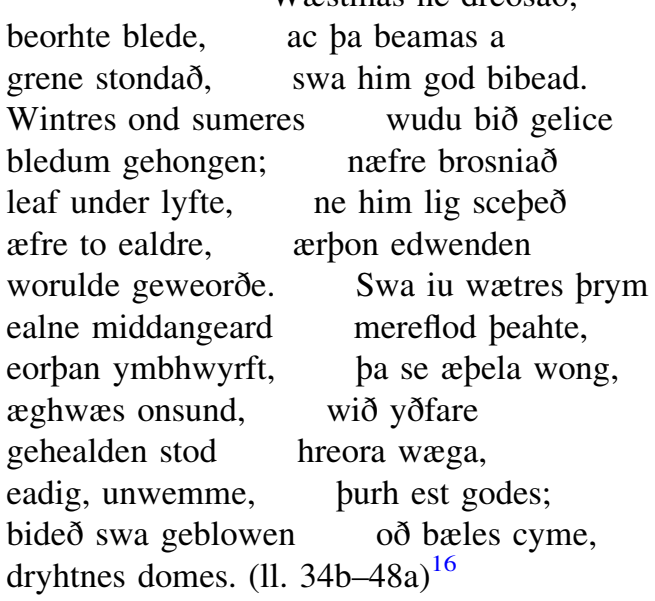

\footnotetext{
12 'There neither mounds nor mountains steeply stand, nor do stone-cliffs tower high, as here with us, nor valleys, nor dales, nor ravines, barrows nor hills, nor does anything rough ever incline there, but the noble field flourishes under clouds, joyfully blooming. The radiant land, that region, is higher by twelve fathoms (so in their wisdom sages knowledgeable from their studies inform us in their writings) than any of the mountains that rear aloft, luminous beneath the constellations, here with us.'

${ }^{13}$ For example 'deopan dala' and 'depan dalo' ('deep dales') of Hell in Genesis B 11. 305a, 421a (Doane 1991, 210, 215); the 'dena dimme' ('gloomy valleys') of Wife's Lament 1. 30a (Muir 2000, 332).

${ }^{14}$ Cf. Advent Lyrics (Christ I) 1. 344a (Muir 2000, 60).

${ }^{15}$ Cf. hlaw, Dictionary of Old English Corpus (Healey et al. 2009) . Hlaw conventionally means 'barrow', although the Dictionary of Old English (Cameron et al. 2016, hereafter DOE) defines hlaw as a natural mound in Phoenix.

16 'Fruits, bright leaves, never fall, but the trees always stand green, as God commanded them. In winter and summer alike the wood is hung with leaves; a leaf never withers under the sky, nor will flame ever injure them, forever, until the end of the world occurs. When formerly the water's surge, sea-flood, engulfed all the world, the earth's surface, that noble plain, stood entirely sound, secure against the rush of the rough waves, blessed, inviolate, through God's grace; so it remains, flourishing, until fire's coming, the Lord's judgement.'
} 
A similar idea is found in the Latin source but without an explicitly Christian context:

Hic solis nemus est et consitus arbore multa

Lucus, perpetuae frondis honore virens.

Cum Phaethonteis flagrasset ab ignibus axis,

Ille locus flammis inviolatus erat,

Et cum diluvium mersisset fluctibus orbem,

Deucalioneas exsuperavit aquas. (11. 9-14) ${ }^{17}$

Again, the poet of The Phoenix employs a Christianizing translation strategy, removing references to Phaethon and Deucalion. As a result, the deluge imagery appears Christianized and the island's escape from the biblical Flood is a sign of its closeness to God. ${ }^{18}$ The Flood, a symbol of chaos and waste sent to punish sin, could not touch the land because it stood inviolate 'purh est godes'. The forces of waste are excluded from this island by God; vegetation does not decay in the deathless space, the trees stand green 'swa him god bibead'. The land of The Phoenix will not decay until Judgement Day because it is protected by God's grace.

The poet returns to the image of the incorrupt land as he concludes his opening description:

\begin{tabular}{|c|c|}
\hline $\begin{array}{l}\text { on pa bearwas } \\
\text { gum wæstmum, } \\
\text { under heofonum, } \\
\text { eallað pær on foldar } \\
\text { dbeama wlite, } \\
\text { am treowum symle } \\
\text { edniwe, in eall } \\
\text { am græswonge } \\
\text { oden hyhtlice } \\
\text { atast bearwa. (ll. } 71\end{array}$ & $\begin{array}{l}\text { pær no } \\
\text { holte } \\
\text { fe }\end{array}$ \\
\hline
\end{tabular}

Imagery of blossoming and fruiting is combined to create a sense of perpetual bounty, not subject to time or seasons, in a clear evocation of Eden. ${ }^{20}$ In Genesis $A$ 11. 206-17 Eden is imagined through a similar set of descriptive

\footnotetext{
17 'Here is the grove of the sun, a holy wood of thickly planted trees, green with the glory of never-failing foliage. When the sky blazed with the fire of Phaethon that spot was unharmed by the flames; and when the flood had overwhelmed the world with its waves it surpassed the waters of Deucalion.'

18 The Old English Orosius implies that Anglo-Saxons might read Deucalion as a type of Noah. Book I.vi records the erroneous interpretation of Deucalion as mankind's progenitor, rather than Noah (Bateley 1980, 24-5). Its Latin source does not make the connection. This interpretation suggests that the substitution of Noah's Flood for Deucalion's in Phoenix is exchanging Christian truth for pagan error.

19 'Those woods are hung with leaves, beautiful fruits, there they, the wood's fruit, never fade, holy under the heavens. Nor do fallow blossoms, the beauty of trees, fall on the ground there, but beauteous, laden branches, ever-new fruit, are always on the trees there, through all time on the grassy plain, the brightest of groves stands green, gaily adorned by the Holy One's might.'

${ }^{20}$ Kabir (2001, 144-47) identifies greenness as a positive characteristic associated with Paradise in Old English religious verse.
} 
commonplaces (Doane 1978, 117). The immutable space is fruiting, well watered, and, like 'The Happy Land', continuously bountiful because it is in a state of grace. Eden is imagined as a reflection of heaven, described in Genesis $A$ as 'beorht and geblædfæst' ('bright and fruitful', 1. 89a) (Doane 1978, 111). The motifs shared by The Phoenix and Genesis A reveal Anglo-Saxon literary conventions for describing the idealized space, wlitig ('fair'), temperate, fruitful and blessed by God.

In an echo of Gen. 2.5-6, Eden in Genesis $A$ has no rain but is watered by a wylleburne ('well-spring') (1. 212a). This image of the welling stream, watering the land, is incorporated into The Phoenix 11. 61a-5 where, in the poem's Christianized landscape, the miraculous fountain of Carmen de ave phoenice 11. 21-8 becomes an emphatic echo of Eden. These controlled and nourishing waters are in contrast to the chaotic water irregularly provided to the rest of the world by the weather. Excess and damaging water is a literary topos associated with waste spaces in Old English texts. It is an uncontrolled force recalling the primordial chaos of the earth and the destruction of the Flood. For example, the inundated landscape of the fen is used metaphorically as an image of waste in the Metrical Epilogue to the Pastoral Care (Dobbie 1942, 111). Uncontrolled, unproductive water lays waste to the landscape, representing the effects of wasted wisdom:

nis ðæt rædlic ðing,

gif swa hlutor wæer, hlud and undiop,

tofloweð æfter feldum oð hit to fenne werð. (11. 19b-21) ${ }^{21}$

Water, like wisdom, has to be controlled and productively used or it is destructive. The water of 'The Happy Land' is not like the waste of the Flood or the fen; this spring nurtures the earth.

The poet of The Phoenix's images reveal a descriptive strategy that draws on both biblical imagery and a distinctly Anglo-Saxon frame of reference, such as weather phenomena which were comprehensively integrated into a Christian understanding of man's relationship to the fallen earth. As discussed below, the insular nature of the phoenix's home belongs to the same kind of pattern. 'The Happy Land' has been reshaped through the Anglo-Saxon imaginaire to illustrate its isolation and present it as an idealized echo of a familiar, insular homeland.

The imagined landscapes of Old English poetry are shaped by a distinctly AngloSaxon way of representing the world, which is often characterized by a preoccupation with apparently insular spaces, the ealond and iglond of Old English verse. Although both words are usually translated as 'island', critics have questioned this interpretation in several Old English poems where the appearance of islands is considered incongruous. Interpreting ealond and iglond as 'island' in The Phoenix is problematized by the absence of any reference to insular space in the Latin source; the same is true of Andreas, in which the poem's principal setting, Mermedonia, is described using igland (1. 15a) and ealand (1. 28a) but no island

\footnotetext{
21 'That is not an advisable thing, if such clear water, loud and shallow, flows over fields until it becomes a fen'. The image, as Godden $(2011,467)$ notes 'evidently develops passages in Chapters 38 and 39 in the Pastoral Care, which are reworkings of Gregory's metaphors'.
} 
occurs in other versions of the narrative (North and Bintley 2016, 118, 119). Other unexpected islands occur in Solomon and Saturn I (11. 1-2a), where the Titan Saturn states: Hwæt! Ic iglanda eallra hæbbel boca onbyrged ('Listen, I have tasted of the books of all the islands') (Anlezark 2009, 60-61). Here igland appears to refer inappositely to the entire world. A similar usage is found in Maxims I (Krapp 1936, 157):

Feorhcynna fela eglond monig. meotud arærde fæpmep wide

Eardas rume for moncynne. (11. 14-16) 22

In order to resolve the problem of these inappropriate islands, critics have argued for extending the semantic range of both ealond and iglond beyond 'island'. George Krapp, who was the first to note the tendency to insert ealond and iglond into the landscapes of Old English verse, argued that one should translate both words as 'land that is reached by water' in these problematic instances (Krapp 1905); his edition of Andreas does just that (Krapp 1906, 410). ${ }^{23}$ Kenneth Brooks, who edited Andreas in 1961, concurred with Krapp's interpretation, stating: 'The meaning is not "island", but "land beyond the water", for Mermedonia is not described as an island in the prose versions' (Brooks 1961, 62). Brooks had earlier discussed the interpretation of the word ealond, citing Andreas as evidence for both ealond and iglond denoting 'water-land', retaining the meaning of their constituent parts, although he did agree that "[b]oth compounds commonly mean "island" (Brooks 1952-1953, 28). ${ }^{24}$ The use of source texts as authorities for the interpretation of Old English poems is problematic, especially when the poets' translation styles are notably selective, expansive and adaptive, as is the case with Andreas and The Phoenix. Yet, Krapp and Brook's assertions are not without linguistic support: the compound ealand does literally mean water-land (Brooks 1952-1953; Cronan 1990). However, its usage in the corpus suggests greater precision of meaning. In describing the location and geography of Ely, the Old English Bede (IV.xix) states it is 'in ealondes gelicnesse' ('in the likeness of an island') (Miller 1890, 324). ${ }^{25}$ If ealond here simply meant 'land that could be reached by water' this description would be peculiar as Ely is land reached by water. Here the translator has understood ealond as expressing insularity, a state that the geography of Ely is like, but is not. There is also a clear terminological distinction made in this text when describing another partial island, Lindisfarne. The translator never uses ealond for Lindisfarne, preferring the more ambiguous $e a$ 'water, water-course, stream, river' (Brooks 1952-1953, 16-27). For example, Old English Bede III.ii, corresponding to Historia Eccelsiastica III.ii, omits Bede's detailed description of Lindisfarne, but

\footnotetext{
22 'Many islands widely contain many living creatures. God established spacious lands for mankind.'

23 The DOE entry for ealond lists Krapp's suggestion as Sense 2.

24 The most recent editors of Andreas (North and Bintley 2016, 219-20, 334, 346) follow this same pattern, imagining Mermedonia not to be an insular space at all.

25 This passage translates Historia Ecclesiastica IV.xix: 'Est autem Elge in prouincia Orientalium Anglorum regio familiarum circiter sexcentarum, in similitudinem insulae uel paludibus ... circumdata uel aquis' ('Ely is a district of about 600 hides in the kingdom of the East Angles and ... resembles an island in that it is surrounded by marshes or by waters') (Colgrave and Mynors 1969, 396-97).
} 
clearly differentiates between its geography and that of the true island Iona, describing Aidan as sent to 'Lindisfarna ea' but as coming 'of pam ealand ond of pam mynstre be Híi is nemned' ('from that island and from that minster which is named Iona') (Miller 1890, 158, 160). Of course, Old English poetry frequently allows a far greater semantic range for a word than prose texts. Nevertheless, there is a compelling argument to be made for interpreting both ealond and iglond in Old English verse as denoting insular space as the landscapes of these poems have been shaped within an Anglo-Saxon imaginaire, which is profoundly influenced by the insular nature of Britain.

In contrast to the editors of Andreas, editors of The Phoenix have tended to favour interpreting both ealond and iglond as 'island' ${ }^{26}$ Editors of Solomon and Saturn I appear undecided. ${ }^{27}$ The use of eglond in Maxims $I$ has received the least critical attention, but is potentially the most important image for understanding how these 'islands' are to be construed in a poetic context, as Charles Wright's analysis of the islands of Old English poetry shows. Wright is the only scholar to have offered a compelling explanation for the use of ealond and iglond in these problematic contexts, engaging with Krapp's suggestion to argue that their use is a 'semantic loan' reflecting the Vulgate Bible's use of insula to evoke distant lands in the formula insulae gentium (Wright 1986). Wright persuasively argues that Maxim I's 'eglond monig' (1. 15a) is influenced by Genesis 10.5, 'Ab his divisae sunt insulae gentium in regionibus suis, unusquisque secundum linguam suam et familias suas in nationibus suis' ('By these were divided the islands of the Gentiles in their lands, every one according to his tongue and their families in their nations.') (Wright 1986, 16). The insulae gentium of the Vulgate have been appropriated by the Anglo-Saxon poet to create an image of the world. While this reading highlights the importance of Christian tradition to the Anglo-Saxon poetic imagination, it does not fully address why such an image of distant lands should be so appealing to the Anglo-Saxons, and be expanded to encompass the entire world. This attraction can be explained by the insular nature of the Anglo-Saxons' own spatial imaginaire.

The unexpected islands of Old English verse are echoes of insulae gentium, but they are perhaps also echoes of one particular 'insula gentis', whose poets latched onto the biblical image because it echoes their own insular space. Genesis 10.5, the passage echoed by Maxims I, refers to the division of lands among the descendants of Japheth, who are credited by Bede, Alcuin and Ælfric with the population of Europe (Kendall 2008, 215; MacLean 1883, 95-96). ${ }^{28}$ Although Genesis 10.5 is interpreted as referring to all Europeans, the use of insula would have drawn the Anglo-Saxons' attention as it echoes the situation of their own land. Accepting that Anglo-Saxon landscapes are derived from an imaginaire based on their own environment as well as their Christian worldview accounts for the insistent recurrence of insular spaces in the corpus. Reading Wright's idea that the islands are

\footnotetext{
${ }^{26}$ Cook $(1919,102,68,97)$ and Blake $(1990,108,115)$. Although Christopher Jones is unwilling to commit to the insularity of the space and translates both words as 'isolated land' (Jones 2012, 19, 37, 379, 81).

27 Menner (1941, 155) offers 'land bordering the sea' as well as island in his glossary. Daniel Anlezark $(2009,60,146)$ translates as 'islands', but lists 'coast' as an alternative in the glossary.

28 Cf. Anlezark (2002, 2006, 278-9).
} 
a reflection of the biblical use of insula to refer to distant lands through an awareness of the Anglo-Saxon spatial imaginaire suggests that the Anglo-Saxons may have perceived these scriptural passages as types of themselves. Anglo-Saxon poets chose islands to echo both Scripture and their own space.

Jennifer O'Reilly (2005) has highlighted the prominence of the island in AngloSaxon Christianity, drawing on the equation of the biblical insula with the apostolic mission in patristic texts. These texts reveal a blurring of literal and metaphorical islands in the interpretation of insula, creating an overlap that would appeal to the Anglo-Saxon mind. Augustine, in his commentary on 'laetentur insulae multae' ('let many islands be glad') in Psalm 96.1 (Dekkers and Fraipont 1956, 1357), views the islands as both literal and metaphorical:

est quidem, quia uerbum dei non in sola continenti terra praedicatum est, sed etiam in insulis quae constitutae sunt in medio mari; et ipsae plenae christianis, plenae sunt seruis dei. non enim separat mare eum qui fecit mare. quo naues possunt accedere, uerba dei non possunt? impletae sunt insulae. uerumtamen possunt et in figura recte accipi insulae, omnes ecclesiae. (par. 4, 11. $13-19)^{29}$

Jerome's Commentariorum in Esaiam connects Isaiah 11.11 to the apostolic mission, as is conventional (Adriaen 1963, 155), before adding 'Et ab insulis maris. Insulas autem maris occidentalem plagam significat, quae oceani ambitu clauditur' ('And from the islands of the sea. Indeed it signifies the islands of the sea's western region, which the circuit of the Ocean encloses'). To an informed Anglo-Saxon reader, recalling Historia ecclesiastica I.i., 'Brittania Oceani insula' (Colgrave and Mynors 1969, 14), amongst other geographic descriptions, the islands enclosed by the ocean include their home, and subsequent references to islands in Isaiah, and elsewhere in Scripture, would take on particular significance. The islands of the gentiles would be read as an echo of the Anglo-Saxons' own space, and their own spiritual history as a converted island, encouraging the depiction of spaces as insular in religious works. ${ }^{30}$ This impulse is manifest in the representation of the land of Mermedonia in Andreas, a poem about the conversion of an island, which uses material from Isaiah (Appleton 2015), and, like The Phoenix, anglicizes the imagery it inherits from its principal source. In this view the use of ealond and iglond in Old English verse echoes the insulae gentium of the Vulgate, as Wright argues, but does so as a reflection of the national space of the island of Britain. The image of the insulae gentium is attractive to the Anglo-Saxons because of the importance of the island to their spatial imaginaire, shaped by the geography they inhabited.

Further blurring of insulae gentium with the image of the island as a familiar Anglo-Saxon ordering of the space is found in the glossing tradition, where both the language and landscape of the text are translated into an Anglo-Saxon form. Wright

\footnotetext{
29 'It is indeed, because the word of God has been preached not only in the continent, but also established in the islands that are in the midst of the sea; and they are full of Christians, full of the servants of God. For the sea cannot separate the One who made the sea. Where ships can approach, cannot the words of God? The isles are filled. Nevertheless, the islands can rightly be taken figuratively for all the churches.'.

${ }^{30}$ Cf. the scriptural echo in Metrical Preface to the Pastoral Care 1. 3a, which describes Augustine bringing the text to the Anglo-Saxons, termed 'iegbuendum' ('island-dwellers') (Dobbie 1942, 110).
} 
has drawn attention to the use of ealond and iglond in biblical glosses as an echo of insulae gentium; these instances can also be seen as a recasting the scriptural landscape within the Anglo-Saxons' insular imaginaire. Owun, the tenth-century glossator of John's Gospel in the Rushworth Gospels (Oxford, Bodleian Library, MS Auct. D.2.19) remaps the geography of the New Testament within an insular perspective, glossing the city of Tiberias on the Sea of Galilee as ealond (Ker 1957, 352; Skeat 1878, 57). He renders John 6.23 as 'oðre soðlice ofer comon sciopu of ðæm ealonde neh ðær stowe ðer gietun pæt bread ðoncunge dydon gode' ('truly other ships came over from that island, near that place where they ate that bread, and did thanks to God'). ${ }^{31}$ This instance is one of the three uses of ealond that the DOE cites under Sense 2 of the word, meaning 'land reached by water', but given the pervasiveness of the island in the Anglo-Saxon spatial imagination it is probable that the space has been imagined as insular, shaped by an imaginative conflation of the Vulgate's use of insulae gentium for distant lands with a more literal idea of the island, suggested by the sea journey (as may have happened in Andreas, where Mermedonia is reached by boat). Owun alters the geographical situation of the Gospel story to reflect an Anglo-Saxon perspective, in which ships crossing the sea to a continent would come from an island such as Britain.

Owun is not alone in having a propensity to gloss spaces as insular. In the earlyeleventh-century Lambeth Psalter (London, Lambeth Palace 427, ff. 1-209) the glossator uniquely uses the word iglond to translate regio in Psalm 105.27 (Lindelöf $1909,171)$. The gloss provided is 'pæt he awurpe sæd ofspryng heora on cynnum on peodum \& forspilde hig on yglondum on eardum' ('That he should throw down the seed of their offspring in kindreds and nations, and spill them on islands in the earth'). Wright regards this image as reflecting the Vulgate's use of insula to mean distant lands (Wright 1986, 14-15). These insulae gentium have been expanded to encompass the world, as in Maxims I. Here again the Anglo-Saxons' perception of inhabited space as insular has influenced how the world is imagined and understood. These glosses translate the landscape of the biblical texts into insular terms, glossing both language and geography. They are an Anglo-Saxon linguistic and rhetorical imposition on the Latin text, reshaping its world within the insular framework of the Anglo-Saxons' spatial imaginaire

The idea that inhabited space is an island, or at least island-like, within the Anglo-Saxon imaginaire illuminates one of the most contentious uses of ealond in the poetic corpus, Beowulf 11. 2333-5a (Fulk, Bjork and Niles 2008, 80): 'Hæfde ligdraca leoda fæsten,I ealond utan, eorðweard ðonel gledum forgrunden' ('The flame-dragon, the earth guarder, had ground the men's stronghold, the island from without, to pieces with flames'). Krapp included this instance in his argument that ealond should be understood as a land reached by water (Krapp 1905, 403-04). Norman Eliason suggested emendation to 'eal ond utan', but this has not found

\footnotetext{
${ }^{31}$ The gloss of the Rushworth Gospels is very closely related to the 10th-c. gloss of the Lindisfarne Gospels, which may be its exemplar (Skeat 1871, xi-xiii). The Lindisfarne gloss does not refer to an island.
} 
universal favour (Eliason 1953). ${ }^{32}$ The editors of Klæber IV tentatively suggest that ealond might be haplography from ealdlond (Fulk, Bjork and Niles 2008, 242). If ealdlond had been the reading of the exemplar, the change to ealond would reveal the insularity of the scribe's perspective: a tendency to imagine inhabited spaces as islands has coloured his reading of the word. Insular spaces shape the imagined worlds of Old English poetry, constructing literary landscapes as echoes of AngloSaxon national space. Following Wright's argument, the use of ealond and iglond in The Phoenix is an echo of the Vulgate's use of insula to evoke distant lands. However, 'The Happy Land' is also an ealond and an iglond because the island orders the occupied space in the Anglo-Saxons' spatial imaginaire, shaped by their own insular landscape.

The island of The Phoenix is both a scriptural echo and a literal island, surrounded by water. The poem's island imagery is sustained beyond the use of the words ealond and iglond. For example, the poet of The Phoenix retains the description of the dawn putting stars to flight from Carmen de ave phoenice 11. 33-6, but the sunrise is recast though the prism of Christian, insular experience:

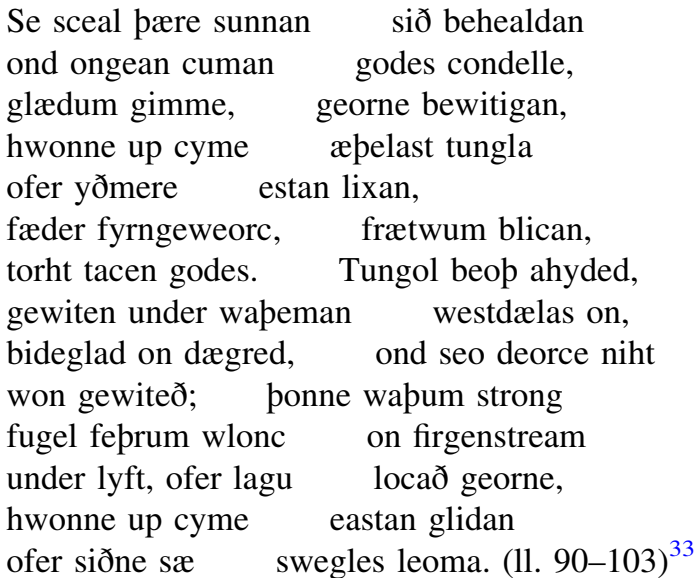

This image of the dawn is strongly associated with the sea-a detail absent from the Latin text. The same image of dawn over water in the east recurs in 11. 287b-290. As Janet Thormann observes, the sea creates a sense of enclosure and separation, dividing the unfallen land of the phoenix from the rest of the fallen earth (Thormann, 1970, 189). This image of separation is also one of insularity: the sun appears in the east over the sea and the stars sink in the sea to the west: the phoenix inhabits an island. There is a sense of envelopment and enclosure created by the

\footnotetext{
32 Although Alfred Bammesberger agrees (Bammesberger 2007).

33 'It (the phoenix) must behold the journey of the sun, go towards God's candle, the shining gem, eagerly observe, when the noblest of stars comes up over the wavy sea, glittering in the east, the ancient work of the Father, splendidly shining, glorious sign of God. Stars are concealed, departed under the waves in western parts, hidden at dawn, and the dark, black night departs; then, strengthened for flight, the bird proud in feathers looks eagerly on the ocean stream under the sky, over the waves, for when the light of heaven comes up the in the east, gliding over the wide sea.'
} 
structure of the poem, the image of the sun and the stars, and the definition of the space as an iglond and an ealond, enhancing the impression of isolation. ${ }^{34}$

The insularity of the space is important to the message that the poet of The Phoenix is attempting to express: the isolated perfection of the space, and its worldly nature. As O'Reilly highlights in her discussion of Bede's use of islands to represent the Anglo-Saxon church, insular space was seen by the Anglo-Saxons as close to heaven and separated from the preoccupations of the world (O'Reilly 2005). Being an iglond is what makes 'The Happy Land' aenlic. The pairing of these words in 'ænlic is pæt iglond' (1. 9a), their shared stress and alliteration, bonds them together as an image in the reader's mind. Yet, 'The Happy Land' is still a part of the world: even for the idyllic island of The Phoenix, the waste will inevitably come. In the Anglo-Saxon poet's Christianized vision the phoenix's home is a part of the earth, and, like all earthly things, it cannot endure. In the final image from his description of 'The Happy Land', the poet emphasizes the inevitable destruction of the phoenix's home with the rest of the world on the Judgement Day:

pæt onwended ne bið

æfre to ealdre, ærpon endige

frod fyrngeweorc se hit on frympe gescop. $(11.82 b-4)^{35}$

The conclusion of this section is a gentle reminder to the reader that all earthly things are mutable, anticipating the explicit eschatological discussion in the poem's latter section. 'The Happy Land' is imagined through the landscape conventions of Old English verse as a sublime but earthly space. It 'bideð swa geblowen oð bæles cyme,I dryhtnes domes' ('so it remains, flourishing, until fire's coming, the Lord's judgement', 11. 47-8a). The phoenix's home is an image of Eden, which hints at the delights of Paradise, but is not eternal.

In Old English verse idealized landscapes are typically presented as a prompt for the contemplation of transience. This association of beauty with decay is found in The Seafarer and The Husband's Message, and exemplified by the opening of Judgement Day II (Dobbie 1942, 58):

$\begin{array}{ll}\text { Eac pær wynwyrta } & \text { weoxon and bleowon } \\ \text { innon pam gemonge } & \text { on ænlicum wonge, } \\ \text { and pa wudubeamas } & \text { wagedon and swegdon } \\ \text { purh winda gryre; } & \text { wolcn wæs gehrered, } \\ \text { and min earme mod } & \text { eal wæs gedrefed. (1l. 5-9) })^{36}\end{array}$

The imagery, expanded from the Latin source, is rather like that of 'The Happy Land' of The Phoenix, or of Paradise from Genesis A: a singular meadow with 'wynwyrta'

\footnotetext{
34 The island as an image of separation is common in Anglo-Saxon hagiography. Cf. saints such as Cuthbert of Lindisfarne, Guthlac of Crowland, and Herbert of Derwentwater. It also occurs in secular texts; Wulf and Eadwacer sets its oblique and emotional narrative on islands, separated by waste.

35 'That will not be changed for ever and ever, before he who created it in the beginning brings to an end the old, ancient work.'

36 'Likewise happy plants were waxing and blooming there in that gathering on a singular plain, and there the trees of the wood were wagging and swaying through the impetus of winds; cloud was stirred, and my wretched mind was all troubled.'
} 
and 'wæterburnan'. ${ }^{37}$ The Old English translator heightens the spring-like nature of the imagery inherited from his source, but tinges it with shadows; the 'winda gryre' with which 'wolcn wæs gehrered' disturbs the idyll. These details show that this is a worldly setting and will decay, leading to the ultimate wasting of the earth by fire on Judgement Day. The eschatological contemplation that occupies the remainder of the poem is already evoked in the fragile beauty of this mutable meadow, just as the worldly beauty of The Phoenix leads to the knowledge of its finite nature. The happy, idealized landscapes of the earth are imagined as fleeting spaces in the Anglo-Saxon corpus-only the eternal landscape of heaven endures. In this fallen world the vernance of spring will fade and die as sin has contaminated the land. As the poet of The Phoenix emphasizes, the earth is a 'geomran woruld' ('sad world', 1. 139b), lasting only until Judgement Day. The poet of The Phoenix's references to the inevitable decay of 'The Happy Land' encourage the reader to focus instead on the immutable landscape of heaven, accessible to humanity through the resurrection of the righteous, the principal subject of the poem.

The imagined landscape of The Phoenix is a cultural construct, reflecting beliefs and assumptions about how natural, human and divine forces shape the world. It is an expression of a particular worldview, which, in the case of the Anglo-Saxons, is Christian and insular. By remapping the landscape of 'The Happy Land' inherited from Carmen de ave phoenice through the Anglo-Saxon imaginaire the poet of The Phoenix is able to open his extended allegory with a vision that resonates with his audience, drawing them into the description of the marvellous bird that follows, which, as Fox has shown (Fox 2012), is shaped by a similar anglicizing strategy. The poet of The Phoenix's reshaping of the landscape anticipates the explicit allegory of judgement and resurrection in the latter section of the poem, in which the phoenix models the righteous' potential for resurrection, and 'The Happy Land' represents the lost Eden, while foreshadowing the permanent home in heaven. The use of images that appear to be conventional in Old English verse suggests a deliberate attempt by the poet to exploit the associations which these carry in support of the poem's allegory. Rather than being prolix or unoriginal, the poet is crafting an effective tool for contemplation. By making the phoenix's home an insular space the poet both highlights its perfection and echoes the space of AngloSaxon England. This evocation of the home heightens the sense of what has been lost with the Fall, and may be regained through the resurrection of the righteous.

Open Access This article is distributed under the terms of the Creative Commons Attribution 4.0 International License (http://creativecommons.org/licenses/by/4.0/), which permits unrestricted use, distribution, and reproduction in any medium, provided you give appropriate credit to the original author(s) and the source, provide a link to the Creative Commons license, and indicate if changes were made.

\section{References}

Adriaen, M. (Ed.) (1963). S. Hieronymi presbyteri opera. Pars 1: Opera exegetica. 2: Commentariorum in Esaiam Libri I-XI. Corpus Christianorum Series Latina 73. Turnhout: Brepols.

\footnotetext{
37 The poem is a translation of De die Iudicii (Hurst and Fraipont 1955, 439-44), a poem attributed to Bede (Allen and Calder 1976, 208-12).
} 
Allen, M. J. B., \& Calder, Daniel G. (Eds.). (1976). Sources and analogues of Old English poetry. Cambridge: D. S. Brewer.

Anlezark, D. (2002). Sceaf, Japheth and the origins of the Anglo-Saxons. Anglo-Saxon England, 31, $13-46$.

Anlezark, D. (2006). Water and fire: The myth of the flood in Anglo-Saxon England. Manchester: Manchester University Press, Manchester Medieval Literature.

Anlezark, D. (Ed.). (2009). The Old English dialogues of Solomon and Saturn. Anglo-Saxon Texts 7. Cambridge: D. S. Brewer.

Appleton, H. (2015). The Book of Isaiah as an influence on Andreas. Notes and Queries, 61(1), 1-6.

Bammesberger, A. (2004). The Old English Phoenix, lines 3b-6. Notes and Queries, 51(3), 223-225.

Bammesberger, A. (2007). Ealond utan at Beowulf, line 2334a. Notes and Queries, 54(4), 361-364.

Bately, J. (Ed.). (1980). The Old English Orosius. Early English Text Society s.s. 6. London: Oxford University Press.

Blake, N. F. (1961). Originality in 'The Phoenix'. Notes and Queries, 8(9), 326-327.

Blake, N. F. (Ed.). (1990). The Phoenix. Exeter Medieval English Texts and Studies. Exeter: University of Exeter Press.

Brooks, K. R. (1952-1953). Old English ea and related words. English and Germanic Studies, 5, 15-66.

Brooks, K. R. (Ed.). (1961). Andreas and the Fates of the Apostles. Oxford: Clarendon.

Brooks, B. (2015). The reorientation of creation in the early Anglo-Saxon vitae of Cuthbert and Guthlac. Oxford: DPhil. University of Oxford.

Bugge, J. (1976). The virgin Phoenix. Mediaeval Studies, 38, 332-350.

Cameron, A., Ashley C. A., Antonette di P. H., et al. (Eds.). (2016). Dictionary of Old English: A to H online. Toronto: Dictionary of Old English Project. http://www.doe.utoronto.ca. Accessed 9 Dec 2016. (DOE).

Colgrave, B., \& Mynors, R. A. B. (Eds. and Trans). (1969). Bede's Ecclesiastical history of the English people. Oxford Medieval Texts. Oxford: Clarendon.

Conybeare, J. J. (1826). Illustrations of Anglo-Saxon poetry. London: Harding and Lepard.

Cook, A. S. (Ed.). (1919). The Old English Elene, Phønix, and Pysiologus. New Haven: Yale University Press.

Cronan, Dennis. (1990). Old English water-lands. English Language Notes, 27, 6-9.

Dekkers, E., \& Fraipont, J. (Eds.). (1956). Sancti Aurelii Augustini Enarrationes in Psalmos. Corpus Christianorum Series Latina 39. Turnhout: Brepols.

Doane, A. N. (Ed.). (1978). Genesis A: A new edition. Madison: University of Wisconsin Press.

Doane, A. N. (Ed.). (1991). The Saxon Genesis: An edition of the West Saxon Genesis B and the Old Saxon Vatican Genesis. Madison: University of Wisconsin Press.

Dobbie, E. V. K. (Ed.). (1942). The Anglo-Saxon minor poems. Anglo-Saxon poetic records 6. London: Routledge.

Eliason, N. E. (1953). Beowulf notes. Anglia, 71, 438-455.

Emerson, O. F. (1926). Originality in Old English poetry. The Review of English Studies, 2(5), 18-31.

Flight, T. (2016). Apophasis, contemplation, and the kenotic moment in Anglo-Saxon literature. Oxford: DPhil. University of Oxford.

Fox, H. E. (2012). The aesthetics of resurrection: Goldwork, the soul, and the deus aurifex in the Phoenix. Review of English Studies, 63(258), 1-19.

Fulk, R. D., Bjork, Robert E., \& Niles, John D. (Eds.). (2008). Klaeber's Beowulf and the Fight at Finnsburg (4th ed.). Toronto: University of Toronto Press.

Godden, M. R. (2011). Prologues and epilogues in the Old English Pastoral care, and their Carolingian models. Journal of English and Germanic Philology, 110(4), 441-473.

Gorst, E. K. C. (2006). Latin sources of the Old English Phoenix. Notes and Queries, 53(2), 13-642.

Hurst, D., \& Fraipont, J. (Eds.). (1955). Beda Venerabilis. Opera homiletica. Opera rhythmica. Corpus Christianorum Series Latina 122. Turnhout: Brepols.

Healey, A. di P., John, P. W., \& Xin, X. (Eds.). (2009). Dictionary of Old English web corpus. Toronto: Dictionary of Old English Project. http://www.doe.utoronto.ca/pages/pub/web-corpus.html. Accessed 12 Dec 2016.

Jones, C. A. (Ed. and Trans). (2012). Old English shorter poems, Vol. 1: Religious and didactic. Dumbarton Oaks Medieval Library 15. Cambridge, MA: Harvard University Press.

Kabir, A. J. (2001) Paradise, death and Doomsday in Anglo-Saxon literature. Cambridge Studies in Anglo-Saxon England 32. Cambridge: Cambridge University Press.

Kantrowitz, J. S. (1964). The Anglo-Saxon 'Phoenix' and tradition. Philological Quarterly, 43(1), 1-13. 
Kendall, C. B. (Trans). (2008). Bede: On Genesis. Translated Texts for Historians 48. Liverpool: Liverpool University Press.

Ker, N. R. (1957). Catalogue of manuscripts containing Anglo-Saxon. Oxford: Clarendon.

Krapp, G. P. (1905). Notes on the Andreas. Modern Philology, 2(3), 403-410.

Krapp, G. P. (Ed.). (1906). Andreas and the Fates of the Apostles: Two Anglo-Saxon narrative poems. Boston, MA: Ginn.

Krapp, G. P. (Ed.). (1936). The Exeter Book. Anglo-Saxon Poetic Records 3. London: Routledge.

Lindelöf, U. (Ed.). (1909). Der Lambeth-Psalter: Eine altenglische Interlinearversion des Psalters in der Hs. 427 der erzbischöflichen Lambeth Palace Library. Helsinki: Druckerei der Finnischen Litteraturgesellschaft.

MacLean, George Edwin (Ed.). (1883). Alfric's Anglo-Saxon version of Alcuini Interrogationes Sigeuulfi presbyteri in Genesin. Halle: E. Karras.

Menner, R. J. (Ed.). (1941). The poetical dialogues of Solomon and Saturn. London: Oxford University Press.

Michelet, Fabienne. (2006). Creation, migration, and conquest: Imaginary geography and sense of space in Old English literature. Oxford: Oxford University Press.

Miller, Thomas (Ed.). (1890). The Old English version of Bede's Ecclesiastical history of the english people. Early English Text Society o.s. 95. London: Trübner.

Muir, B. J. (Ed.). (2000). The Exeter anthology of Old English poetry: An edition of Exeter Dean and Chapter Ms 3501. Exeter Medieval Texts and Studies (2nd ed., Vol. 2). Exeter: University of Exeter Press.

Neville, J. (1999). Representations of the natural world in Old English poetry. Cambridge Studies in Anglo-Saxon England 27. Cambridge: Cambridge University Press.

North, Richard, \& Bintley, Michael (Eds.). (2016). Andreas: An edition. Exeter Medieval Texts and Studies. Liverpool: Liverpool University Press.

O'Reilly, J. (2005). Islands and idols at the ends of the earth: Exegesis and conversion in Bede's Historia Ecclesiastica. In Stéphane, L., Michel, P., \& Olivier, S. (Eds.), Bède le vénérable: entre tradition et postérité (pp. 119-145). Lille: Centre de Gestion de l'Édition Scientifique, Université Charles-deGaule, Lille 3.

Raw, B. C. (1978). The art and background of Old English poetry. London: Edward Arnold.

Scragg, D. (Ed.). (1992). The Vercelli homilies and related texts. Early English Text Society o.s. 300. Oxford: Oxford University Press.

Shaw, B. A. (1989). The Old English Phoenix. In Jeanette Beer (Ed.), Medieval translators and their craft (pp. 155-183). Kalamazoo, MI: Western Michigan University, Medieval Institute Publications.

Skeat, W. W. (Ed.). (1871). The Gospel according to Saint Mark: In Anglo-Saxon and Northumbrian versions, synoptically arranged with collations exhibiting all the readings of all the Mss. Cambridge: Cambridge University Press.

Skeat, W. W. (Ed.). (1878). The Gospel according to Saint John: In Anglo-Saxon and Northumbrian versions, synoptically arranged with collations exhibiting all the readings of all the Mss. Cambridge: Cambridge University Press.

Steen, J. (2008). Verse and virtuosity: The adaptation of Latin rhetoric in Old English poetry. Toronto: University of Toronto Press.

Sweet, H. (Ed.). (1881). An Anglo-Saxon reader in prose and verse. Oxford: Clarendon Press.

Szarmach, P. E. (Ed.). (1981). Vercelli homilies IX-XXIII. Toronto: University of Toronto Press.

Thormann, J. (1970). Variations on the theme of 'the hero on the beach' in the Phoenix. Neuphilologische Mitteilungen, 71(2), 187-190.

Vollmer, F. (Ed.). (1905). Dracontius, de laudibus Dei (Vol. 1). Monumenta Germaniae historica auctores antiquissimi 14. Berlin: Weidmann.

Wilcox, J. (1997). Variant texts of an Old English homily; Vercelli X and stylistic readers. In P. E. Szarmach \& J. T. Rosenthal (Eds.), The preservation and transmission of Anglo-Saxon culture: Selected papers from the 1991 meeting of the International Society of Anglo-Saxonists (pp. 35-354). Kalamazoo, MI: Western Michigan University, Medieval Institute Publications.

Wright, C. D. (1986). Insulae gentium: Biblical influence on Old English poetic vocabulary. In A. Groos (Ed.), Magister regis: Studies in honor of Robert Earl Kaske (pp. 9-22). New York: Fordham University Press. 